\title{
Malaysia KESBAN Counterinsurgency Model: A Pathway for Combating the Islamist Boko Harm in the Northern Nigeria
}

\author{
Modu Lawan Gana ${ }^{1}$ and Hadiza Mali Bukar ${ }^{2}$ \\ ${ }^{1}$ Lecturer, Mai Idris Alooma Polytechnic, Yobe State, Nigeria \\ ${ }^{2}$ Lecturer, Yobe State University, Yobe State, Nigeria
}

\begin{tabular}{ll} 
ARTICLE INFO & ABSTRACT \\
\cline { 2 - 3 } $\begin{array}{l}\text { Keywords: } \\
\text { KESBnterinsurgency }\end{array}$ & $\begin{array}{l}\text { This article analyzed the KESBAN counterinsurgency model of Malaysia } \\
\text { in combating the Communist Movement in 1989. It compares with the } \\
\text { ongoing Nigerian government counterinsurgency against the Islamist Boko }\end{array}$ \\
Boko Haram & $\begin{array}{l}\text { Haram group in the country. The empirical data gathered from secondary } \\
\text { materials including both published and unpublished materials. The article } \\
\text { Malaysia }\end{array}$ \\
revealed that the successes of the Malaysian combating the communist \\
rebellion was influences by its KESBAN model premised on the heart and \\
mind strategy in its campaign. It hence revealed that the protraction of the \\
Boko Haram rebellion is promoted partly by the enemy-centered campaign \\
of the government. The uses of excessive military force on fighters and \\
implementing draconian laws targeting the host population bolstered the \\
insurgent group. It enabled them accesses to logistics and intelligence thus \\
influence the extension of its violence. As a panacea, the article suggest \\
that Nigeria should borrow from Malaysia's KESBAN model in its \\
operation. On against the prevailing security only campaign, the \\
government should adopt the Malaysia strategies of establishing new \\
villages and raising of home guards to control the population. The \\
Government should also focus on implementing economic empowerment \\
programs for the resettled population.
\end{tabular}

\section{Introduction}

Nigeria and Malaysia despite the differences of geographical location, the two countries shared many commonalities in respect to climate, economic, and political situations. In the political scene, both Malaysia and Nigeria are colonies of Great Britain that obtained political independence after World War two. Both countries are structured on the federal political system. Nigeria is divided into 36 states, whereas Malaysia is divided into 13 states. The populations in both countries are heterogeneous fiercely divided between ethnic and religious lines. Islam is the largest religion in Malaysia, followed by Christianity, Hinduism, Buddhism, and some elements of Sikh practitioners. Islam and Christianity are the popular religion in Nigeria. However, there are emerging trends of atheism in the country in recent times.

Linguistically, arising from their colonial history, both countries use the English language as a medium of communication. However, in recent time, Malaysia change the English as a second language in the country. Moreover, both countries after their political independence fought a

* Corresponding author E-mail address: gana.lawan@yahoo.com

Cite this article as:

Gana, M. L. \& Mali Bukar, H. (2021). Malaysia Kesban Counterinsurgency Model: A Pathway for Combating the Islamist Boko Harm in the Northern Nigeria. Journal of Advanced Research in Social Sciences, 4(1), 52-60. https://doi.org/10.33422/jarss.v4i1.513

(C) The Author(s). 2021 Open Access. This article is distributed under the terms of the Creative Commons Attribution 4.0 International License, which permits unrestricted use, distribution, and redistribution in any medium, provided that the original author(s) and source are credited. 
protracted insurgency crisis. Malaysia fought a communist struggle orchestrated by the Communist Party of Malaysia (CPM) between 1956 and 1989. Nigeria after ended about 30 months of civil war in 1970 with a secessionist Biafra movement, in 2009, it appeared to another deadly insurgency by an Islamic fundamentalist Boko Haram in the country's north. Perhaps, much like the political system, the Malaysia CPM insurgency and the Nigeria Boko Haram insurgency share many commonalities both in respect to their motivations and the modus operandi of the group. Whereas the former mainly an ideological struggle aimed at establishing a communist state in Malaysia, the latter is a quasi-ideological struggle aimed at establishing an Islamic State in northern Nigeria that should be adjudicate with spiritual injunctions of Islamic holy books. Concerning the modus operandi, both insurgents use the armed violence involving guerilla attacks, suicide bombing, arson, and drive-by shootings targeting state security operatives and government establishments. In both countries, the insurgency operates along the border areas. The CPM largely operate along the Malaysia eastern border with Thailand, the Boko Haram operates in the Nigeria eastern borders with Niger, Chad and Cameroun republics.

Nevertheless, despite the similarity patterns of their politics and insurgency threats, Malaysia successfully terminated the insurgency in 1989 thus ended the communist movement in the country. Nigeria however, after nearly a decade of counterinsurgency (COIN) operation, the insurgent Boko Haram continuously mounting threats to the country's political existence. Besides the catastrophic damages of social and economic assets, Boko Haram is reportedly controlling large swaths of the Nigerian landmass occupied by the civil population. Accounts differs, however, there is popular believe that the successes of Malaysia in combating the Maoist insurgency is influenced by its adoption of the KESBAN model. The model is premised on the people-centered operation combining a dual technique of security and economic development. Hence, we argued that the protraction of the Boko Haram insurgency is influences by the kinetic COIN approach of the Nigeria government. Although, there is growing evidence of people-centered operation by the Nigeria government over the years, however, we insist, there are number of missing links comparative to the Malaysia KESBAN model. Therefore, the article proposed that, as a pathway to terminate the Boko Haram rebellion, Nigeria should learn from the KESBAN strategy. In addressing this, this article proceeded in five sections. Section one presented the methodological approach of the study. Section two is the review of the insurgency situation in Malaysia. Section three is a review of the Boko Haram insurgency in Nigeria. Section four presented the Malaysia KESBAN model. Section five is the analysis of the missing link of the Nigeria COIN in respect to the KESBAN model, and section six is the conclusion and recommendation of the study.

\section{Methodology}

This is a concept paper. The empirical data obtained through review of scholarly articles including but not limited to journal articles, thesis, magazines, and textbooks. All materials are selected base on critical analysis of the quality of the previous sources, the reliability/reputability of the publishers, as well as timing of the publications. Each chosen article is critically studied and the data compared with other sources. The trustworthiness of the article hence depends on the in-depth and critically of its analysis.

\section{Literature review}

\subsection{The communist insurgency in Malaysia}

From 1948 until the year 1989, the Malaysian government fought a deadly insurgency perpetrated by the Communist Party of Malaysia (CPM). The participants of the insurgency who are mostly of the ethnic Chinese population received tacit support from the People Republic of China (Hussein, 2013). The insurgents disregarded Malaysia as a sovereign state. 
Therefore, fought to establish a communist state to be govern strictly on the Maoist principles. In addition to the colossal damages of human and material capitals, the ethnic coloration of the insurgency triggered antagonism between the Chinese and the indigenous Malay population. Most of the indigenous Malay population regarded the Chinese as immigrants bended to destabilize the Malaysia society. Issues of economic and political domination and marginalization further promote the antagonistic relation. The overall effect hence refueled the insurgency. For instance, since Malaysia political independence, there is a growing accusation by the minority ethnic group that the Malay population dominated the political space of the country. On the contrary, the Malay also accuses the Chinese expatriates for dominating the economic space subjected the Malay population to background responsibilities (Komer, 1972). Consequently, the insurgency and racial dispute reached its peak after the Malaysia general election in 1969. The excruciating defeat of the CPM in the election resulted in the eruption of violence leaving prominent personalities murdered. Most of the deaths are of the ethnic Malay population. On 17 June 1968, for instance, the CPM rebels launched an ambush on the Security Forces in Kroh-Bentong leaving about 17 security forces murdered (Talib, 2005). Others are the assassination of Tan Sri Abdul Rahman bin Hashim, the Inspector-General of Police (Stubbs, 1977; Ong and Ramakrishna, 2013). Despite the concerted COIN measures, the insurgency survived until 1989 when a peace accord was signed between the government and the rebel group. Although accounts differ, however, some estimates have shown that nearly 1200 rebel layoff arms for the peace deal (Talib, 2005). Table 1 showed the estimates of fatalities recorded during the peace accord.

Table 1.

Causalities during Malaysia insurgency

\begin{tabular}{lcccc}
\hline & Killed & Wounded & Captured & Surrendered \\
\hline Guerrilla & 212 & Not defined & 150 & 117 \\
Security Forces & 155 & 854 & - & - \\
Total & 365 & 854 & 150 & 117 \\
\hline
\end{tabular}

Source: Talib (2005:22)

\subsection{The Boko haram insurgency in Nigeria}

The Boko Haram is a Sunni Islamist group of the Salafi-Wahhabi variant in northern Nigeria. It is translates, as "Western education is a sacrilege". It erupted into armed violence with the Nigerian state since 2009. Its objectives are quite dynamic. Obasi (2015) stressed that Boko Haram's strategic goals have evolved over time. However, the initial objective is to forcedly evict the formal state system in Nigeria and constitute an Islamic state to be adjudicates with the spiritual laws of Islam. The group is also critical to all forms of civilizations including attending schools, civil service, democracies, and foreign diplomacies. The earlier strategy is largely on Gandhi civil disobedient tactics such as isolations from the population, sit-in, and subversion. The impetus of violence emerged in July 2009 in a weeklong anti-government and anti-west armed campaign in Maiduguri, a city of about 2 million population (Onuoha, 2012). The uprising conservatively left about 1000 people murdered (Agbiboa 2018; Pham, 2012; Shuabu et al, 2015). The majority of the deaths are of the group members including Mohammed Yusuf, the spiritual leader of the movement.

The brutal attack of the insurgent reached its height when Abubakar Shekau, an erstwhile deputy of the late Yusuf assumed the groups' leadership. The group under Shekau engaged in frequented attacks on government and private establishments including the attack on United Nations Office buildings. On 26 August 2011, the group attacked United Nations office in Abuja, the Nigeria's capital city and killed 25 people and over 80 others wounded (Pham, 2012). As a show of supremacy, in June 2011 the insurgent exploded vehicle-borne improvised devices on the convoy of Nigeria police General (Popovski and Maiangwa, 2016; Pham, 2012). 
Although, official statistics of attacks are scarce, however, Azuma (2014) documented that the insurgent is responsible for 31 attacks on Churches; 43 attacks on Mosques, and dozens on schools and government establishments in 2012. Through its indiscriminate use of force, Boko Haram frustrated the formal education in northeast Nigeria. The region is previously notorious for its educational backwardness among the six geopolitical zones of the country. Indices of Nigeria's Bureau of Statistic in 2010 shows $72 \%$ of school-age children in Borno State, the spiritual home of the Boko Haram are out of school. The forceful abduction of over 270 high school girls at Chibok town further frustrated the effort of girl child education in northern Nigeria.

Consequently, despite the COIN approach, Boko Haram pushes and seize control of swathes of Nigeria land covering about 24 local councils in the northeast. Some authors have equated the territorial land control by the Boko Haram to that of Belgium (Gana et al, 2018a). State authorities in Nigeria often claimed to be on top of the Boko Haram rebellion, however, spectacular attacks continuously reported in the national dailies. There is a general belief unless a decisive measure is ensure, Nigeria should be the next exporter of global fundamentalist groups in Africa. In this article, we proposed that Nigeria should adopt the Malaysian KESBAN model to terminate the Boko Haram rebellion.

\section{The Malaysia KESBAN model}

Malaysia despite the complexity of its insurgency, the country is notorious for its successful counterinsurgency operation around the world (Hussein, 2013; Ridzuan et al., 2014). The Malaysia COIN strategy is multifaceted involving both aggression (enemy), and the democratic (people-centered) approaches. The dominant account however is that of the people-centered approach that prioritize democratic control of the population, improving governance through provision of basic social services. The rationale is to enhance the legitimacy of the government. Sequel to this approach, the government promulgated the 'KESBAN model.' It is an acronyms of KESELAMATAN and PEMBANGUNAN, literally 'Security and Development' adopted by Tun Abdul Razak Bin Hussien Al-Haj, the second Prime Minister of Malaysia (Wahab and Teh, 2015; Ong, 2010). The Figure 1 shows the diagram of the KESBAN Model.

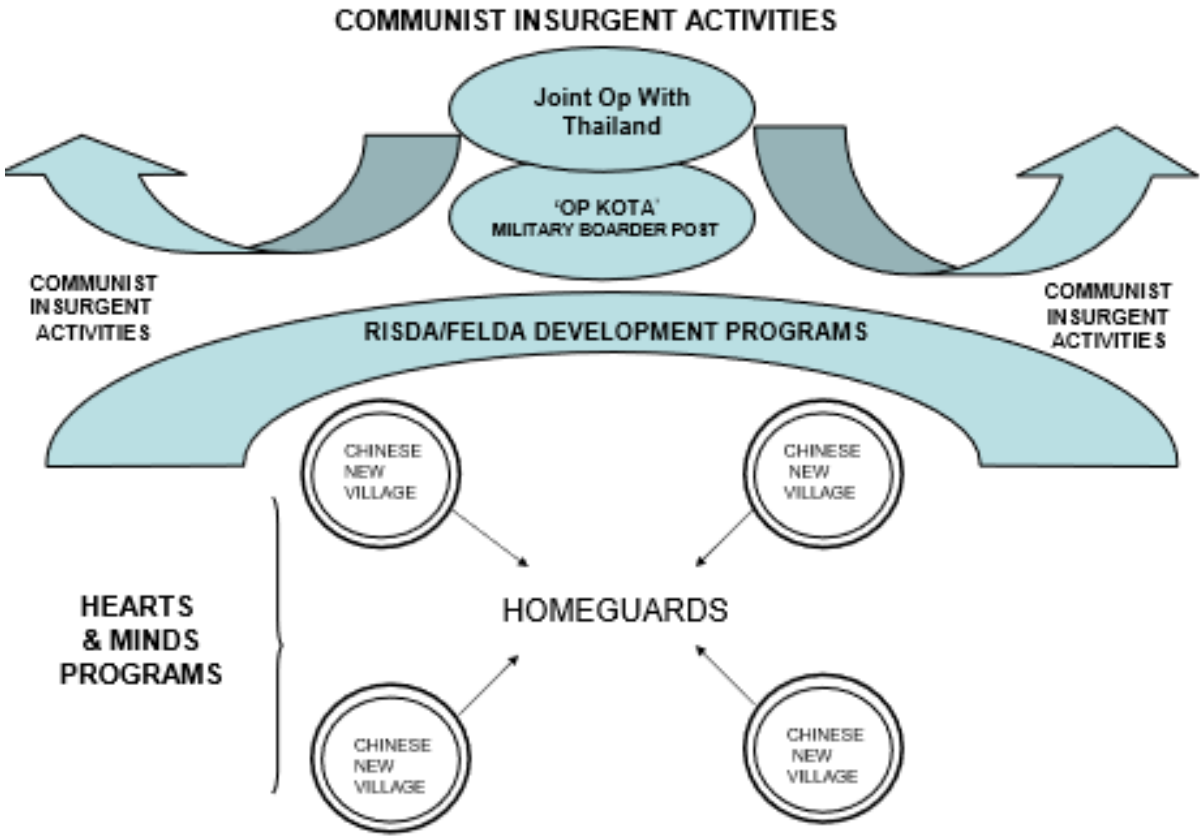

Figure 1. Malaysia KESBAN MODEL

Source: Yadi (2004:31) 
As the figure 1.1 shows, the KESBAN model emphasized the principle of containment in combating the communist group without losing the confidence of the population. The model focus on undermining the communist group through suppressing its supplies of logistic from the villages. In most respect, the idea of the KESBAN is rooted from the assumption that governance and development are instrumental for COIN successes. The strategy besides simplified the provision of basic service to the population, it influences sufficient control of the population by the government. Through this process, the insurgent recruitment chain is thwarted, its supply routes of foods and logistics stripped. Arising from this strategy, nearly half a million of the Chinese population resettled in about 450 settlements (Uckho, 2017; Ridzuan et al., 2014).

Simultaneously with the governance approach, the Malaysia government also expanded the size of the police force through the recruitment of home guards. Majority of participants in the home guard are the indigenous Malay population. About 90,000 of the auxiliary forces engaged as a force multiplier to the regular force. Nearly three-fourth assembled in the villages (kampong) providing security to the rural population (Komer, 1972). The military on the other hand pushes the non-repenting insurgent around the border areas. The KESBAN assumed that the exigency of the CPM arises from the adoption of the draconian laws and harsh policies by government targeting both the insurgent and rural populations. As a solution, it combined security and development. It is in this context, Talib (2005:19) defined the program as a sum of all measures undertaken by the Malaysian Armed Forces and government agencies in protecting the population. The strategy emanated from the fish and water analogue of Mao Tse Sung. Mao equated guerrilla to a fish and the population to a river. He stressed that just as how a fish will die when the river is drains from it; the guerilla will turn helpless when the population withdraw its support. Beyond the security-economy approach, the KESBAN also exploited certain anthropological factors of race, social class, and culture of the host population.

\section{The KESBAN model and the lesson for Nigeria}

Malaysia CPM insurgency shares several similarities with the Nigeria Bok Haram group. Despite the similarities patterns of their insurgency threat, Malaysia successfully terminated the CPM in 1989. However, Nigeria still encounter spectacular attacks from the Boko Haram group. The successes' of the Malaysian government was grounded from its adoption of the KESBAN model. Although, the extant literature have indicated some attributes of peoplecentered strategy in the Nigeria COIN approach, conspicuously demonstrated through the programs of Demobilization, Deradicalization, Rehabilitation and Reintegration (DDRR) of repentant terrorist, however, the prevailing evidence suggest that the bulk of the Nigeria COIN is concentrated on the kinetic approach. Kinetic is a category of COIN campaign that prioritizes the use of brutal force in crushing fighters and maiming the host population to withdraw support for the rebels. The reality of this argument is tenable from the government deployments of numerous Special Forces and engagement in transnational forces.

There is popular believe that Boko Haram witnessed the highest deployment of security force to civil rebellion in the political history of Nigeria. Presently, there are an estimated 100,000 members of the Nigerian security operatives fighting the Boko Haram in the northeast. In Maiduguri alone, a city of about 2 million populations, there are about 8,000 members of the Nigerian armed force. Some authors have claimed that the military aggression is probably responsible for the protraction of the Boko Haram rebellion in the country (Gana, Samsu, and Ismail, 2018b). Pundits have argued that excessive force triggers support for the insurgent, curtail counterinsurgents' access to vital intelligence thus bolsters the insurgent group. Galula (1964) pointed out that using force exacerbates insurgency, undermined the counterinsurgents' support of the population, and denies firsthand intelligence. At the worst, it provokes public 
grievances toward the COIN operators, and undermine public confidence toward the government. This assertion might be observe from the series disputes and protest over the presences of the armies in the northeast (Gana et al. 2020a).

Therefore, the main missing link in the Nigeria operation comparative to the KESBAN model is the heart and mind approach. Notable in this regard is the establishment of the Chinese villages and erection of the home guards. The creation of the Chines villages enabled the Malaysian government to resettle the Chines population, successfully isolated, arrest, and detained fighters. The home guards equipped with anthropological knowledge over the host population and technical skills on the physical terrain, efficiently exercised control on the population, access vital intelligence and cut off the insurgent supports from the population. Numerous experts (Galula, 1964; Thompson, 1966) have popularize the incredible role of intelligence on successful COIN operation.

However, in respect to the Nigeria, the government is yet to establish the home guard. Observably, there is inadequate support for the self-created pro-government militia 'Civilian Joint Task Force' (CJTF) in the northeast by the federal government. The militia CJTF was formed out of frustration of the persistency of the insurgency in 2013. In spite of its influence in intelligence collection and processions, their stipends and logistics solemnly lies with the state governments in the northeast. Notably, the 10,000-member CJTF militia conspicuously undersize to cover the vast geographical terrain occupied by the Boko Haram. In Malaysia, despite the territorial diminutive, there are estimated 90,000 members of the home guards rightly armed and finance by the Malaysian government. Moreover, while the Malaysia government under the KESBAN program propounded Chinese villages solemnly to resettle the displaced population, to date, the Nigeria's government resettlement strategy focused on the establishment of internal displacement camps in the capital cities. The consequences of these displacement camps are enormous. In addition to the situational factors of overcrowding, feeding, and hygiene issues, the unwarranted competition on the already constraint social amenities in the urban centers by the intruding populations instigated rivalry between the displaced population and the host communities. This communal suspicion was heighten with the incessant attacks and bomb explosions in the displacement camps. In most instances, the host communities accuses the displaced population for harboring the insurgent fighters to leach terror on the localities.

Furthermore, the KESBAN model promotes economic development through the rural agricultural program 'FELDA.' In Nigeria, there is inadequate program that specifically targets the displaced population. Most of the displacement interventions are in food aids given in piecemeal by the government and, the non-governmental organizations. Therefore, most of the displaced population in Nigeria are food dependents. The food aid service came with associated challenges, among others it encourages idleness, hence making people a potential recruitment fool of the Boko Haram group. The truism of this can be deduce from the popular saying, 'an idle mind is a devil workshop'.

Consequently, the Malaysian Government understands the importance of population control by allowing people to maintain their domestic security in the form of Home Guards. In doing this, the government allows the indigenous people to provide for their security needs. The government however, provided the necessary support, and ensured control of the Home Guards to prevent excessiveness. In the case of Nigeria, the COIN is mainly a federal government affair. This strategy has numerous challenges. Besides, the associated factors of the delay in passing commands and receiving feedbacks, the concentration of the COIN at realm of federal government manifested in inappropriate deployment of troops to the war zone. Presently, most troops in the Nigeria war zones are alien to the states. Certain sociocultural differences of languages, religion and ethnicity with the host population keeps the armies isolated from the host communities they tend to securitize. In most of the northeast, the troops are confined to 
dip trenches in the outskirts of the towns and villages. Besides the difficulties in the adaptation to the climates, most troops also lacks the technical knowledge of the physical terrain of the insurgent operation. The combined effect thus undermine their operational successes. The reality is evident in the frequented but avoidable ambushes fallen by the Nigeria armies on patrol duties in the northeast.

\section{Conclusion}

In general, the article revealed that Nigeria applied a combined tactics of people-centered and enemy-centered approach in its COIN campaign. However, the aggression tactics preoccupy the bulk of the counterinsurgency strategy. The government use military force and enacts draconian laws targeting both the rebels and the host population to withdraw support for the insurgents. The enemy-centered approach of the government bolstered the insurgents' support and denied the government firsthand intelligence about the insurgent movements and its hideout. In most respect, this strategy negates to the KESBAN model of the Malaysian government. Comparatively, whereas the KESBAN premised on the heart and mind technique guaranteed through dual tactics of providing security and economic empowerment, the Nigerian counterinsurgency strategy mainly centered on the enemy approach. The campaign focused on the indiscriminate killing of fighters, suspected and alleged collaborators. It also aimed to declare the host population as potential enemies. Arising from this strategy, the Boko Haram continue to earn sympathy from the aggrieve population; consistently receive intelligence about the troop's movements and its location. The article pointed out the later as the probably reason for the avoidable ambushes on the Nigeria army in the northeast. The combined effects of these influences the Boko Haram to protract its violence. As a panacea, the article suggest that Nigeria's government should learn from the Malaysia KESBAN model.

1. Since the home guard is instrumental to the Malaysia successes, the Nigerian government should raise and arm similar force in the insurgent affected states. Members of the home guard must be drawn from the host communities.

2. Against the establishment of Internal Displacement Camps, the government should focus on establishing new villages where the fleeing population can be settle. The home guards should provide the policing function in the villages, while the military should exercise supervisory roles.

3. Beyond the security role, the government should focus on providing basic social amenities to the new settlements. This will promote support for the government and undermine the insurgent's legitimacy.

4. The Nigeria government and its development partners should engage in creating conducive economic development climates through the provision of economic empowerment skills and soft loans to the resettled population. This should be simultaneously or against the preexisting food only interventions to the displaced population.

5. Since the insurgents exploit the porous international boundaries in the northeast, in addition to the Multinational Joint Task Force whose mandate is mainly aggressive transnational pursuit of the terrorist, the Nigerian government should re-collaborate with each of the neighbouring states in the areas of border patrol around the territorial borders.

\section{Acknowledgements}

The author would like to thank the Tertiary Education Trust Fund (TETfund) in Nigeria for worthy of supporting the research. Thank you the Management of Mai Idris Alooma Polytechnic, Geidam for recommending the study to the TETfund. Special thanks to all the research participants that took time to give valuable information to the researcher. 


\section{Conflict of interest}

There is no conflict of interest in this article.

\section{Reference}

Agbiboa, D.E. (2018): Eyes on the Street: Civilian Joint Task Force and the Surveillance of Boko Haram in Northeastern Nigeria, Intelligence and National Security, pp. 1-19.

Galula, D. (1964), Counterinsurgency Warfare: Theory and Practice. Praeger Security International Westport, Connecticut, London.

Galula, D. (1964), Counterinsurgency Warfare: Theory and Practice. Praeger Security International Westport, Connecticut, London.

Gana M.L. (2020a). Militia Counterinsurgency. Perspective on the Motivations of Civilian Joint Task Force Militia Participation in Northern Nigeria. RUDN Journal of Public Administration; Vol.7 (2): 124-134. DOI: 10.22363/2312 8313-2020-7-2-124-134

Gana, M.L (2019a). Militia Participation in Counterinsurgency: The Impetus of Civilian Joint Task Force Participation in Combating Boko Haram in Nigeria, RUDN Journal of Political Science, Vol.21.3, pp.460-469

Gana, M.L (2020b). Strategy of Civilian Joint Task Force Militia in Combating Boko Haram in Northern Nigeria, International Journal of Legal Studies, Vol. 1 (7), 345-360 DOI: $10.5604 / 01.3001 .0014 .3126$

Gana, M.L., Samsu, K. H \& Ismail, M.M (2018a). Counterinsurgency Responses in Nigeria: Unveiling the Constraining Challenges, International Journal of Arts Humanities and Social Sciences Vol. 3.6, pp. 1-8

Gana, M.L., Samsu, K.H \& Ismail, M.M. (2018b). Population-Centric Counterinsurgency: The Conduit for Ending Boko Haram Insurgency in Nigeria's North. European Journal of Behavioral Sciences, 1 (4): 8-13.

Gana, M.L., Samsu, K.H \& Ismail, M.M. (2019b). Civil Disobedience to Violent Extremism: Understanding Boko Haram in Nigeria, International Journal of Research in Social Sciences, Vol. 8(1), 1-5,

Hussein, H.T. (2013). Managing Complex Security Challenges: Historical Perspectives, Traditional Sovereignty, Nation Building and Collective Approaches, Journal of Defence and Security, Vol, 4.2, pp. 111-118

Komer, R. W (1972). The Malayan Emergency in Retrospect: Organization of A Successful Counterinsurgency Effort. Advanced Research Projects Agency, Report No. R-957-ARPA

Mantzikos, I. (2014). Boko Haram Attacks in Nigeria and Neighbouring Countries: A Chronology of Attacks Perspectives on Terrorism, Vol. 8. 6, pp. 63-81

Obasi, N (2015). The soldiers are less motivated than the Boko Haram insurgents, International Crisis Group.

Ong, W (2010). Securing the Population from Insurgency and Subversion in the Second Emergency (1968-1981), PhD Thesis Submitted to the University of Exeter.

Onuoha, F. C. (2012). Reports Boko Haram: Nigeria’s Extremist Islamic Sect. Al-Jazeera Centre for Studies.

Pham, J.P. (2016) Boko Haram: The Strategic Evolution of the Islamic State's West Africa Province, The Journal of the Middle East and Africa, Vol. 7.1, pp-18. 
Popovski, V., \& Maiangwa, B. (2016). Boko Haram's Attacks and the People's Response: A "Fourth Pillar" of the Responsibility to Protect? African Security Review, Vol.25.2, pp. $159-175$.

Ridzuan, A.Z., Ismail, $Z$ and Kadir, J.A (2014).Managing Civil-Military Relations in Counterinsurgency Operations: A Review of the Malaysian Experiences, Zulfaqar Int. J. Polit. Def. Secur. Vol. 1, pp. 29-36

Shuaibu, S.S \& Salleh, M.A. (2015). Historical Evolution of Boko Haram in Nigeria: Causes and Solutions. Proceedings of International Conference on Empowering Islamic Civilization in the 21st Century (ICIC2015). Universiti Sultan Zainal Abidin, Malaysia

Talib, N, B (2005). Malaysia's Experience in War Against Communist Insurgency and its Relevance to The Present Situation In Iraq, United States Marine Corps, Command and Staff College, Marine Corps Combat Development, Marine Corps

Thompson, R. (1966). Defeating Communist Insurgency; the Lessons of Malaya and Vietnam (New York: F.A. Praeger).

Ucko, D. H. (2017). Counterinsurgency as armed reform: The Political History of the Malayan Emergency. Journal of Strategic Studies, pp. 1-32.

Wahab, A.Y.A \& Teh, W.H.W (2015). Counterinsurgency through KESBAN: Tun Razak's Administration, 7th International Conference on Humanities and Social Sciences, ASEAN 2015: Challenges and Opportunities (Proceedings)

Yadi, M.Z (2004). Malaysian Emergencies - Anthropological Factors in the Success of Malaysia's Counterinsurgency, Master of Science Thesis Submitted Naval Postgraduate School Monterey, California 